\title{
Advances in Automotive Conversion Coatings during Pretreatment of the Body Structure: A Review
}

\author{
Mark Doerre ${ }^{1, *}$, Larry Hibbitts ${ }^{2}$, Gabriela Patrick ${ }^{2}$ and Nelson K. Akafuah ${ }^{1}$ (i) \\ 1 IR4TD, College of Engineering, University of Kentucky, Lexington, KY 40506, USA; nelson.akafuah@uky.edu \\ 2 Paint Production Engineering, Toyota Motor North America, Inc. (TMNA), Georgetown, KY 40324, USA; \\ larry.hibbitts@toyota.com (L.H.); gabriela.patrick@toyota.com (G.P.) \\ * Correspondence: mark.doerre@uky.edu
}

Received: 7 September 2018; Accepted: 10 November 2018; Published: 15 November 2018

\begin{abstract}
Automotive conversion coatings consist of layers of materials that are chemically applied to the body structures of vehicles before painting to improve corrosion protection and paint adhesion. These coatings are a consequence of surface-based chemical reactions and are sandwiched between paint layers and the base metal; the chemical reactions involved distinctly classify conversion coatings from other coating technologies. Although the tri-cationic conversion coating bath chemistry that was developed around the end of the 20th century remains persistent, environmental, health, and cost issues favor a new generation of greener methods and materials such as zirconium. Environmental forces driving lightweight material selection during automobile body design are possibly more influential for transitioning to zirconium than the concerns regarding the body coating process. The chemistry involved in some conversion coatings processing has been known for over 100 years. However, recent advances in chemical processing, changes in the components used for vehicle body structures, environmental considerations and costs have prompted the automobile industry to embrace new conversion coatings technologies. These are discussed herein along with a historical perspective that has led to the use of current conversion coatings technologies. In addition, future directions for automobile body conversion coatings are discussed that may affect conversion coatings in the age of multi-material body structures.
\end{abstract}

Keywords: design for environment; conversion coating; zirconium; lightweighting

\section{Introduction}

In a 1911 US Patent [1], Thomas Coslett described the use of six ounces of zinc, a pint of water, and a pint of phosphoric acid as ingredients for making a conversion coating concentrate. Its efficacy was demonstrated when iron objects boiled in a water solution made from this concentrate displayed a significant reduction in corrosion as a consequence of a protective zinc phosphate coating that had been formed on the surface of the iron.

The definition of a conversion coating is a coating formed during surface-based chemical reactions that include the base metal and other ions present in solution. Being a direct consequence of surface reactions differentiates a conversion coating from other coatings such as paint: paint is really a covering. Since 1911, vastly improved conversion coating compositions have included various elements in the periodic table and now include numerous organic and inorganic compounds.

Although the evolution of conversion coatings started with iron requiring more corrosion protection, other metals such as zinc and aluminum are also now beneficiaries of conversion coating technologies. For example, automotive bodies have incorporated $\mathrm{Zn}$ as a sacrificial anode in the form of galvanneal (GA), or electrogalvanneal (EG)-treated steel and $\mathrm{Al}$, a lightweight substitute for steel. Paints, or other organic coatings, have improved adhesion characteristics because of a roughened 
surface that is created by the conversion coatings; in other words, a conversion coating also functions to improve the mechanical anchor profile for paint.

The canned food and beverage industries have exerted significant influence on the development of new metal ion chemistries for conversion coatings that have improved coating appearance after container pasteurization and the adhesion of decorative organic coatings. By the 21st century, environmental concerns weighed in on chromates, heavy metal sludge, phosphates, and energy consumption. The long-term combination of these forces have nudged conversion coating technologies to Zr-based materials, a trend noted by David Chalk of Dubois Chemical as the "shrinking periodic table" [2].

\section{The Automotive Coating Stack}

Figure 1 illustrates a typical stack of coatings that are applied onto an automotive body during the painting process [3]; the layers of these coatings add beneficial attributes as noted in the left-hand side of the Figure. However, a customer in an automobile dealer showroom only senses the upper three layers of the "paint job", which include a clear coat, base coat or color (possibly with optional metal flakes) and a primer; these coverings are typically organic in nature. Layer 4 below the coverings is an electro-deposition (ED) coating, and layer 5 is the phosphate conversion coating. The activation layer below the phosphate layer-i.e., between the phosphate layer and the steel body panel—typically consists of Ti or $\mathrm{Zn}$ but does not have a thickness per se because it is made of noncontiguous particles applied under specifications that call for an application based on a weight-per-unit area.

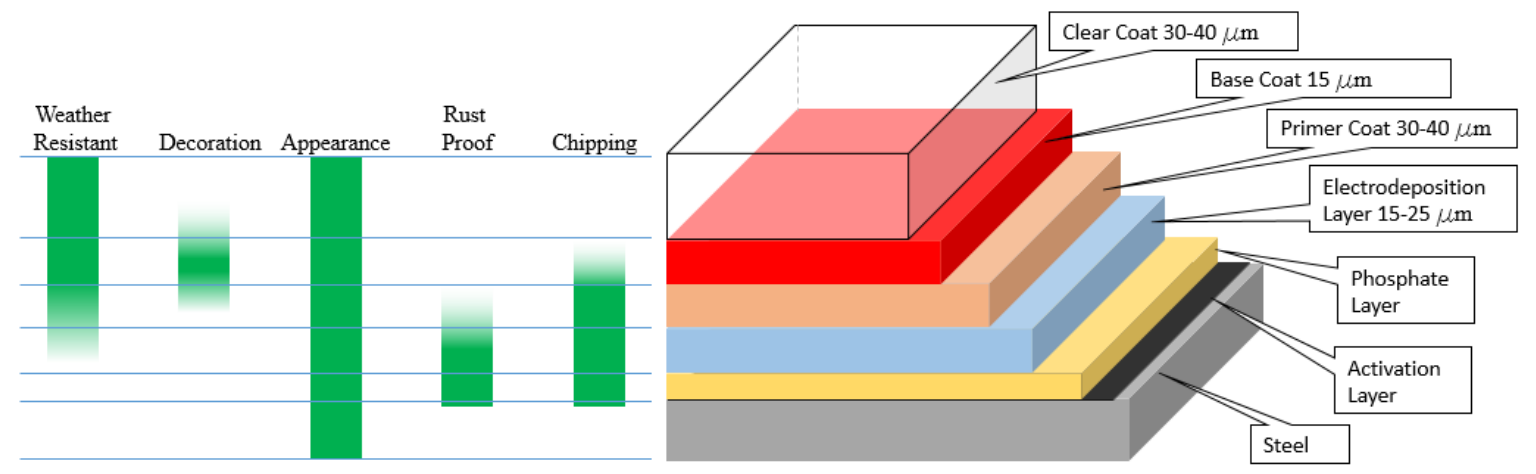

Figure 1. Vertical stack on an automotive body panel with a phosphate conversion coating (not drawn to scale) [3].

\section{The Automotive Conversion Coating Timeline and Purpose}

A timeline for phosphate conversion coating technologies is given in Figure 2; starting at around 1940, it notes some significant milestones [4]. The conversion coatings serve two primary purposes on vehicle bodies. First, they increase corrosion protection when compared to an untreated metal surface; second, they promote adhesion between the paint and metal, creating a more robust bond than in the case of paint applied directly to metal. Together, these effects act as a system that is more tolerant of chemical and mechanical attacks on the body panel surface. 


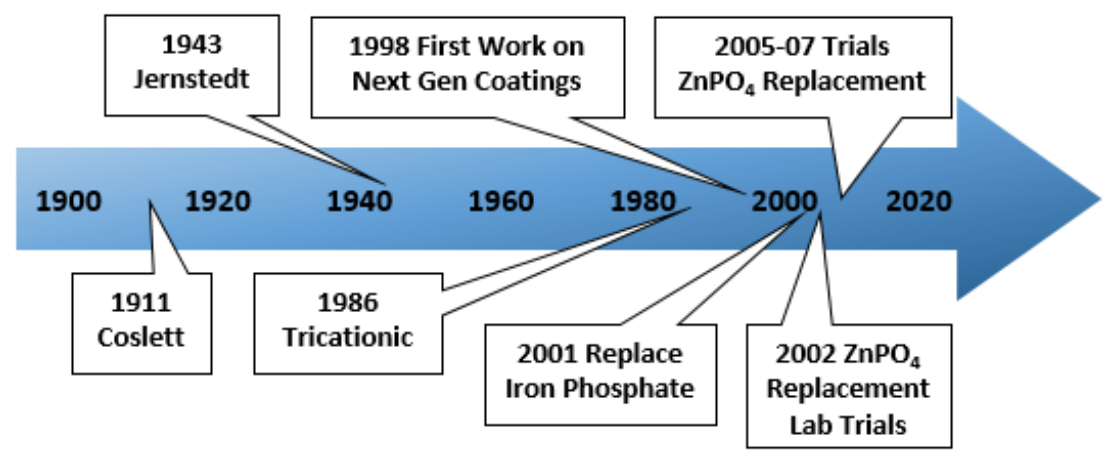

Figure 2. Significant milestones in the progress of phosphate conversion coating technology.

\section{The Foundation of Zinc Phosphate Conversion Coatings}

Figure 3 is presented because discussions found later in this article require some familiarity with the chemical reactions associated with the application of a conversion coating; these reactions include $\mathrm{pH}$-driven precipitation, acid disassociation, oxidation, reduction and redox, the $\mathrm{pH}$ gradient boundary layer, and chromate rinsing. In its simplest form, a zinc phosphate coating starts with oxidation at a surface micro-anode when an Fe atom dissolves into the phosphoric acid solution as a $\mathrm{Fe}^{2+}$ cation and leaves behind two electrons on the base metal. Simultaneously, reduction occurs at a surface micro-cathode. The two electrons residing on the metal then combine with $\mathrm{H}^{+}$in the solution to form surface-adsorbed hydrogen. These reactions are described in Equations (1) and (2) [5].

$$
\begin{gathered}
\mathrm{Fe} \rightarrow \mathrm{Fe}^{2+}+2 \mathrm{e}^{-} \text {(Anode-Oxidation) } \\
2 \mathrm{H}^{+}+2 \mathrm{e}^{-} \rightarrow 2 \mathrm{H}_{\text {sur }} \rightarrow \mathrm{H}_{2} \text { (Cathode-Reduction) }
\end{gathered}
$$

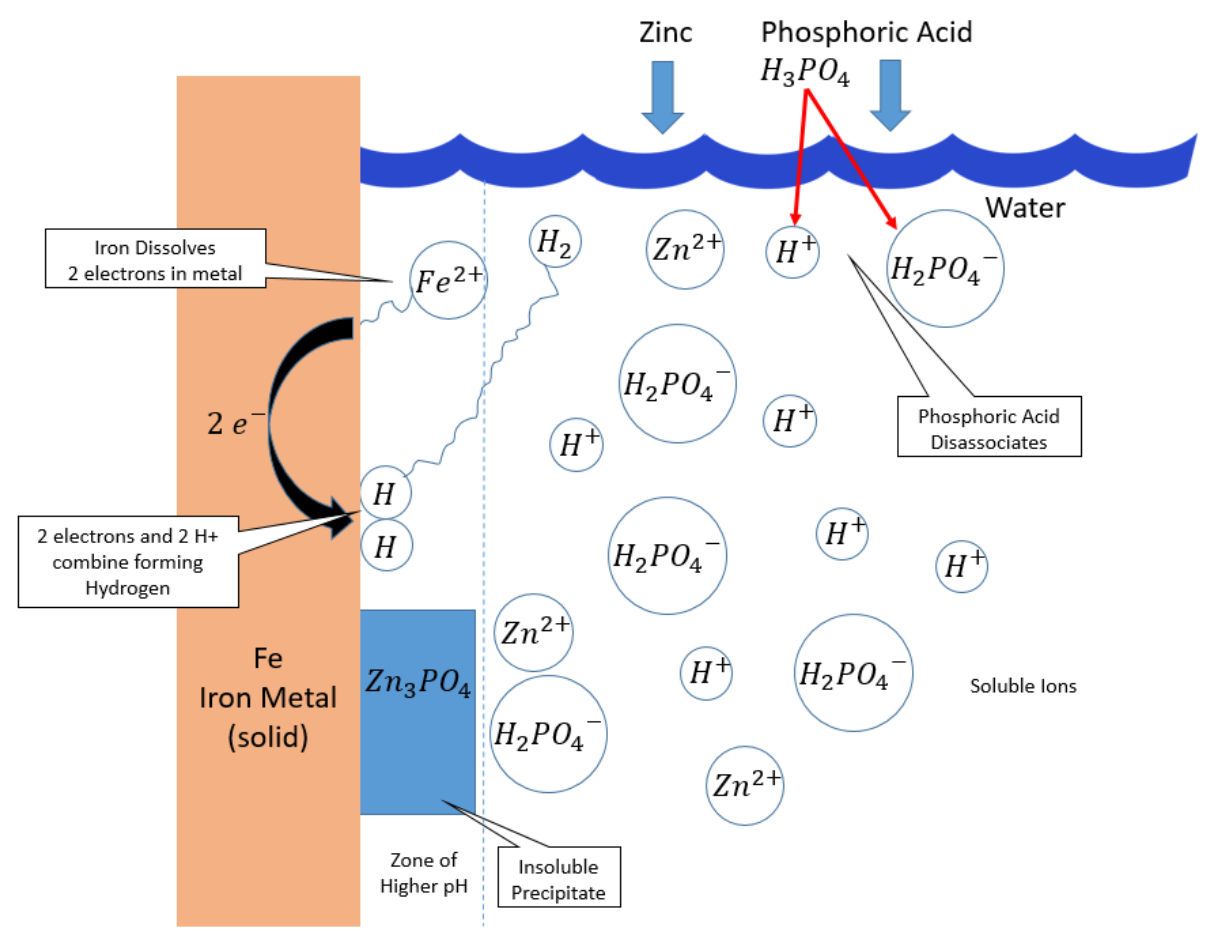

Figure 3. Simplified mechanism of zinc phosphate conversion coating (pH around 3).

Microscopic anodes and cathodes exist on a metal surface due to slight differences in potential caused by minute surface irregularities such as grain boundaries or intermetallic particles. In other words, a uniform potential on the surface of an automobile during conversion coating is a concept that 
does not exist in an assembly plant environment. The slight differences in surface potential create an imbalance that causes a cascade of spontaneous reactions that ultimately form a conversion coating.

By combining Equations (1) and (2), the redox reaction in Equation (3) is created, which has the net effect of producing an $\mathrm{H}^{+}$, or acid, which spontaneously accepts electrons from Fe and forms hydrogen gas. This redox reaction continues as long as the base metal is oxidizing.

$$
\mathrm{Fe}+2 \mathrm{H}^{+} \rightarrow \mathrm{Fe}^{2+}+\mathrm{H}_{2}
$$

A decrease in the acidity $\left(\mathrm{H}^{+}\right)$adjacent to the metal surface establishes the conditions needed for the precipitation of metal phosphate. For example, Equations (4) and (5) describe the equilibrium between primary and tertiary phosphates of $\mathrm{Zn}$ and Fe. On the left side of each equation is a dissolved, water-soluble primary phosphate, whereas on the right-hand side is an acid-soluble tertiary phosphate that becomes insoluble as the acidity $\left(\mathrm{H}^{+}\right)$decreases. Since the acidity is lower at the surface- due to the consumption of $\mathrm{H}^{+}$- the tertiary phosphate precipitates on the surface and forms the conversion coating.

When a conversion coating nearly covers the surface of a base metal, the redox reaction terminates. For Fe and Zn cations, hopeite and phosphophyllite are often called "phases" within a zinc conversion coating that is specific to a steel surface. Depending on the ion content in the solution and the specific metal surface, other "phases" are also possible [6].

$$
\begin{aligned}
& 3 \mathrm{Zn}^{2+}+2 \mathrm{H}_{2} \mathrm{PO}_{4}{ }^{-}+4 \mathrm{H}_{2} \mathrm{O} \leftrightarrow \mathrm{Zn}_{3}\left(\mathrm{PO}_{4}\right)_{2} \cdot 4 \mathrm{H}_{2} \mathrm{O} \text { precipítate }+4 \mathrm{H}^{+} \text {Hopeite } \\
& \mathrm{Fe}^{2+}+2 \mathrm{Zn}^{2+}+2 \mathrm{H}_{2} \mathrm{PO}_{4}^{-}+4 \mathrm{H}_{2} \mathrm{O} \leftrightarrow \mathrm{FeZn}_{2}\left(\mathrm{PO}_{4}\right)_{2} \cdot 4 \mathrm{H}_{2} \mathrm{O} \text { precipitate }+4 \mathrm{H}^{+} \quad \text { Phosphophyllite }
\end{aligned}
$$

In summary, acid consumption at the metal surface causes a local decrease in acidity and this decrease causes acid soluble compounds to precipitate locally out of solution in the form of mineral deposits on the metal surface.

In reality, industrial conversion baths are much more complicated than this example. However, the reactions given in Equations (1) through (5), once understood, enable the understanding of a wealth of knowledge contained in academic and industrial publications about conversion coatings.

A list of reactions for several ions and metal surfaces found in automotive bodies are presented in the following [7]:

Steel

Pickling $\quad \mathrm{Fe}+2 \mathrm{H}_{3} \mathrm{PO}_{4} \rightarrow \mathrm{Fe}\left(\mathrm{H}_{2} \mathrm{PO}_{4}\right)_{2}+\mathrm{H}_{2}(\mathrm{~g})$

Coating

$\mathrm{Fe}+2 \mathrm{H}^{+} \rightarrow \mathrm{Fe}^{2+}+\mathrm{H}_{2}(\mathrm{~g})$

Coating $\quad 3 \mathrm{Zn}^{2+}+2 \mathrm{H}_{2} \mathrm{PO}_{4}^{-}+4 \mathrm{H}_{2} \mathrm{O} \rightarrow \mathrm{Zn}_{3}\left(\mathrm{PO}_{4}\right)_{2} \cdot 4 \mathrm{H}_{2} \mathrm{O}(\mathrm{s})+4 \mathrm{H}^{+}$Hopeite

$2 \mathrm{Zn}^{2+}+\mathrm{Fe}^{2+}+2 \mathrm{H}_{2} \mathrm{PO}_{4}{ }^{-}+4 \mathrm{H}_{2} \mathrm{O} \rightarrow \mathrm{Zn} 2 \mathrm{Fe}\left(\mathrm{PO}_{4}\right)_{2} \cdot 4 \mathrm{H}_{2} \mathrm{O}(\mathrm{s})+4 \mathrm{H}^{+}$Phosphophyllite

$\mathrm{Zn}^{2+}+2 \mathrm{Mn}^{2+}+2 \mathrm{H}_{2} \mathrm{PO}_{4}{ }^{-}+4 \mathrm{H}_{2} \mathrm{O} \rightarrow \mathrm{Mn}_{2} \mathrm{Zn}\left(\mathrm{PO}_{4}\right)_{2} \cdot 4 \mathrm{H}_{2} \mathrm{O}(\mathrm{s})+4 \mathrm{H}^{+} \quad \mathrm{ZnMn}-$ Phosphate

Sludge

$\mathrm{Fe}^{2+}+\mathrm{H}^{+}+\mathrm{O}_{x} \rightarrow \mathrm{Fe}^{3+}+\mathrm{HO}_{x}$

Zinc-Coated Steel

$\mathrm{Fe}^{3+}+\mathrm{H}_{2} \mathrm{PO}_{4}^{-} \rightarrow \mathrm{FePO}_{4}+2 \mathrm{H}^{+}$

Pickling

$\mathrm{Zn}+2 \mathrm{H}_{3} \mathrm{PO}_{4} \rightarrow \mathrm{Zn}\left(\mathrm{H}_{2} \mathrm{PO}_{4}\right)_{2}+\mathrm{H}_{2}(\mathrm{~g})$

$\mathrm{Zn}+2 \mathrm{H}^{+} \rightarrow \mathrm{Zn}^{2+}+\mathrm{H}_{2}(\mathrm{~g})$

Coating

$3 \mathrm{Zn}^{2+}+2 \mathrm{H}_{2} \mathrm{PO}_{4}{ }^{-}+4 \mathrm{H}_{2} \mathrm{O} \rightarrow \mathrm{Zn}_{3}\left(\mathrm{PO}_{4}\right)_{2} \cdot 4 \mathrm{H}_{2} \mathrm{O}(\mathrm{s})+4 \mathrm{H}^{+}$

$\mathrm{Zn}^{2+}+2 \mathrm{Mn}^{2+}+2 \mathrm{H}_{2} \mathrm{PO}_{4}^{-}+4 \mathrm{H}_{2} \mathrm{O} \rightarrow \mathrm{Mn}_{2} \mathrm{Zn}\left(\mathrm{PO}_{4}\right)_{2} \cdot 4 \mathrm{H}_{2} \mathrm{O}(\mathrm{s})+4 \mathrm{H}^{+}$

Aluminum

Pickling

$\mathrm{Al}_{2} \mathrm{O}_{3}+6 \mathrm{H}^{+} \rightarrow 2 \mathrm{Al}^{3+}+3 \mathrm{H}_{2} \mathrm{O}$

Complexing

$\mathrm{Al}+3 \mathrm{H}^{+} \rightarrow \mathrm{Al}^{3+}+1 \frac{1}{2} \mathrm{H}_{2}(\mathrm{~g})$

Coating

$\mathrm{Al}^{3+}+6 \mathrm{~F}^{-} \rightarrow \mathrm{AlF}_{6}{ }^{3-}$

Coating

$3 \mathrm{Zn}^{2+}+2 \mathrm{H}_{2} \mathrm{PO}_{4}{ }^{-}+4 \mathrm{H}_{2} \mathrm{O} \rightarrow \mathrm{Zn}_{3}\left(\mathrm{PO}_{4}\right)_{2} \cdot 4 \mathrm{H}_{2} \mathrm{O}(\mathrm{s})+4 \mathrm{H}^{+}$

$\mathrm{Zn}^{2+}+2 \mathrm{Mn}^{2+}+2 \mathrm{H}_{2} \mathrm{PO}_{4}^{-}+4 \mathrm{H}_{2} \mathrm{O} \rightarrow \mathrm{Mn}_{2} \mathrm{Zn}\left(\mathrm{PO}_{4}\right)_{2} \cdot 4 \mathrm{H}_{2} \mathrm{O}(\mathrm{s})+4 \mathrm{H}^{+}$

Sludge

$\mathrm{Al}^{3+}+6 \mathrm{~F}^{-}+3 \mathrm{Na}^{+} \rightarrow \mathrm{Na}_{3} \mathrm{AlF}_{6}$

$\mathrm{Al}^{3+}+6 \mathrm{~F}^{-}+2 \mathrm{~K}^{+}+\mathrm{Na}^{+} \rightarrow \mathrm{K}_{2} \mathrm{NaAlF}_{6}$ 
The item listed as sludge in the foregoing is a form of waste from conversion coating processing that has several associated negative impacts. First, sludge is a process contaminant; it must be maintained within strict specifications to control operational costs. Second, it has regionally varying disposal costs. Third, as the automotive industry strives for zero-emissions wherever possible, the process linked to creating a sludge becomes a candidate for disruptive replacement.

\subsection{Phosphoric Acid}

Phosphoric acid is known to establish three disassociation reactions in water. Around a $\mathrm{pH}$ of 3 , Equation (6) shows disassociation to form $\mathrm{H}_{2} \mathrm{PO}_{4}{ }^{-}$(aq) ions that are also available as participants in the left side of Equations (4) and (5).

$$
\begin{gathered}
\mathrm{H}_{3} \mathrm{PO}_{4}(\mathrm{~s})+\mathrm{H}_{2} \mathrm{O}(\mathrm{l}) \rightleftharpoons \mathrm{H}_{3} \mathrm{O}^{+}(\mathrm{aq})+\mathrm{H}_{2} \mathrm{PO}_{4}{ }^{-}(\mathrm{aq}) \\
\mathrm{H}_{2} \mathrm{PO}_{4}{ }^{-}(\mathrm{aq})+\mathrm{H}_{2} \mathrm{O}(\mathrm{l}) \rightleftharpoons \mathrm{H}_{3} \mathrm{O}^{+}(\mathrm{aq})+\mathrm{HPO}_{4}{ }^{2-}(\mathrm{aq}) \\
\mathrm{HPO}_{4}{ }^{2-}(\mathrm{aq})+\mathrm{H}_{2} \mathrm{O}(\mathrm{l}) \rightleftharpoons \mathrm{H}_{3} \mathrm{O}^{+}(\mathrm{aq})+\mathrm{PO}_{4}{ }^{3-}(\mathrm{aq})
\end{gathered}
$$

The disassociation reactions in Equations (7) and (8) occur at a higher $\mathrm{pH}$ level than those for Equation (6), as shown in Figure 4.

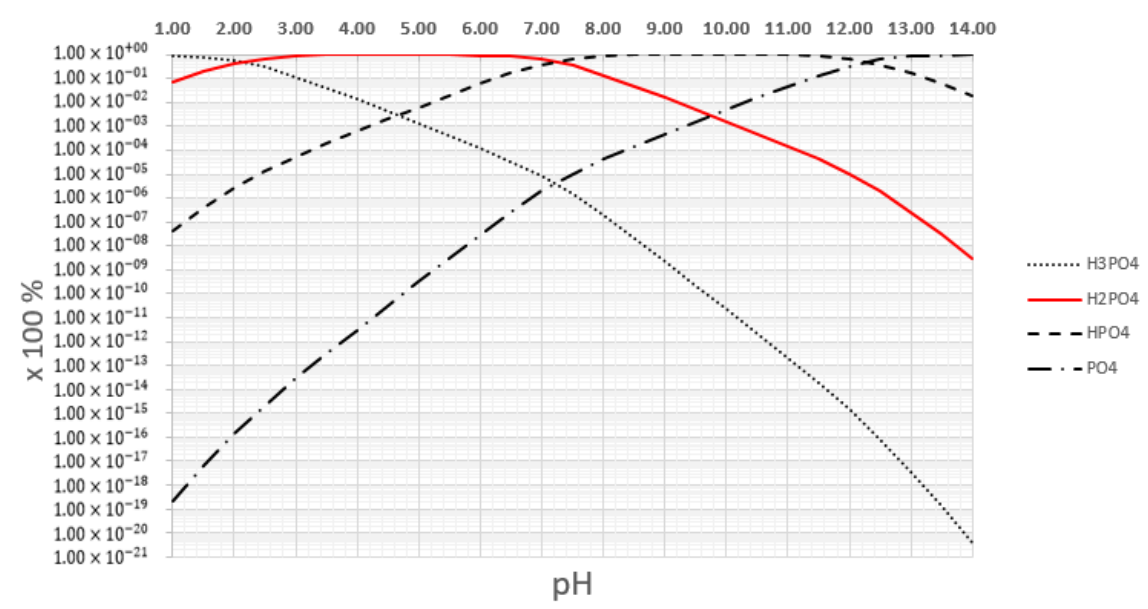

Figure 4. Phosphoric acid disassociations in water.

\subsection{Jernstedt Salt}

The conversion coating process was relatively slow until the discovery of an activation treatment that enabled rapid phosphate growth [8]. Done prior to phosphating, the activation treatment includes a water-based colloid that produces a random deposition of surface-bound particles that are not necessarily contiguous. For this reason, it is a treatment instead of a layer since it has no apparent thickness.

As indicated in Figure 2, George Jernstedt in 1943 invented an aqueous-based activation coating consisting of colloidal titanium phosphate [9]. His Jernstedt salt was a breakthrough that reduced processing time and improved the robustness of zinc-phosphate conversion coatings. In his patent, he claimed a composition that reduced the coating time from a fraction of an hour to about a minute. In addition, the resulting crystal structure was finer, and $\mathrm{Zn}$ more readily participated in the conversion coating. Unfortunately, the patent did not explain the underlying mechanism leading to these improvements.

The titanium phosphate activation process has been illuminated [10] to show that the activation solution has disc-shaped particles with $\mathrm{Na}_{4} \mathrm{TiO}\left(\mathrm{PO}_{4}\right)_{2} \cdot 0-7 \mathrm{H}_{2} \mathrm{O}$ that adsorbs onto an object dipped into the bath solution. A following step in which an object is subsequently placed into a zinc phosphate solution includes the formation of sodium ions on the micro-surfaces of the adsorbed particles and 
exchange with $\mathrm{Zn}$ ions from the phosphate solution. Once these nucleation-enabling surfaces form, local crystal growth, or conversion coating formation, is rapid.

\subsection{Oxidizing Agents}

Oxidizers added to a phosphate solution react with $\mathrm{H}^{+}$ions and electrons $\left(\mathrm{e}^{-}\right)$and further reduce acidity, or increase $\mathrm{pH}$, at the metal surface. Oxidizers also prevent the growth of hydrogen gas bubbles that block phosphate solution contact with the metal surface. The role of an oxidizing agent in a phosphating solution using nitrite is shown in Equation (9) [11].

$$
\mathrm{NO}_{2}{ }^{-}+2 \mathrm{H}^{+}+\mathrm{e}^{-} \rightarrow \mathrm{NO}+\mathrm{H}_{2} \mathrm{O}
$$

Oxidizers are reaction accelerators. Examples of oxidizers include, but are not limited to, nitrate, nitrite, chlorate, peroxide and hydroxylamine sulfate.

Other methods of accelerating the phosphating reaction include adding metal ions such as $\mathrm{Cu}$ to the solution. Copper deposits on the metal surface and increases the number of sites where cathodic reactions can occur. Agitation also accelerates the coating process by preventing the stagnation of ion-depleted solutions.

Klusmann and Schultze used a microelectrode to measure $\mathrm{pH}$ gradients in the proximity of a metal reaction surface [11]; the tip of the microelectrode had a diameter near or less than $1 \mu \mathrm{m}$. Figure 5 displays the $\mathrm{pH}$ changes as a function of the normal distance from a surface. Depending on the amount of oxidizer, a family of $\mathrm{pH}$ gradient curves extends to about $700 \mu \mathrm{m}$ from the surface. Increasing the accelerator concentration causes a larger change in $\mathrm{pH}$ in the zone of limited diffusion near the surface. It has been shown [11] that the most important accelerating factor was the consumption of $\mathrm{H}^{+}$in the zone of limited diffusion near the surface; this factor also combines with the elimination of hydrogen bubbles that otherwise block surface reactions. In summary, the work of Klusmann and Schultze [11] demonstrated the physical dimensions associated with $\mathrm{pH}$ gradients near a surface and the effect of oxidizer concentration on this boundary layer.

\section{$\Delta \mathrm{pH}$ vs. Distance from Surface $\mu \mathrm{m}$ at $\mathrm{mM} \mathrm{NaNO}$}

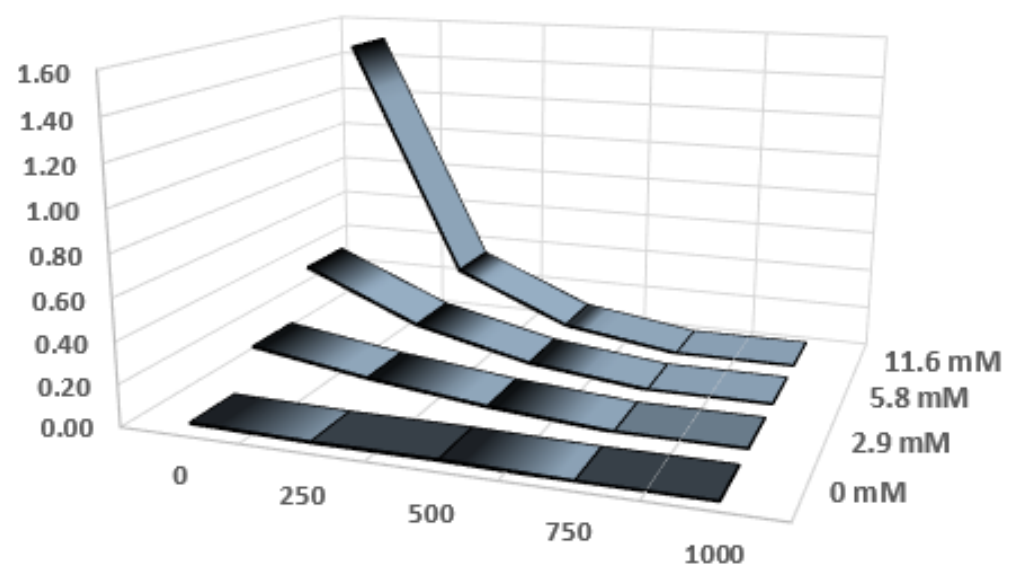

Figure 5. Changes in boundary layer $\mathrm{pH}$ as a function of oxidizer concentration and distance.

\subsection{Chromate Rinse}

Both phosphate and chromate conversion coatings have been, arguably, the most important metal treatments for protecting against corrosion [12]. Phosphate coating followed by treatment with a chromic acid rinse was shown to add further corrosion protection [13]. The primary action of the chromic acid rinsing was to decrease the porosity of the phosphate coatings; in addition, 
the chromate layer created during the acid rinsing provided a corrosion protection barrier and a self-healing mechanism. Self-healing is due to soluble hexavalent chrome migrating to defects in the phosphate coating where it undergoes reduction to chrome (III), forming an insoluble protective barrier of chromium hydroxide [13]. Although the phrase "self-healing" has connotations of a self-sustaining system, continued exposure to a corrosive environment eventually depletes the chromate layer of chrome (VI) and, eventually, eliminates the ability to self-heal reaction [14].

Despite the excellent anti-corrosion performance of chromate rinse and phosphate conversion coatings, the toxicity of chrome (VI) was the impetus to find alternatives to these treatments $[15,16]$.

\subsection{Environmental Terminology}

Several "environmental terms" are ubiquitous in conversion coating literature. Hence, the following discussion elucidates the origin and meanings of these terms.

Phosphates finding their way into waters and wetlands were shown to contribute to eutrophication and an over-nourishment of plant life. Additionally [17], nitrates can mobilize geological sulphates, which in turn interfere with phosphates bound to iron. Plants compete for nutrients when nutrients are scarce [18]; on the other hand, plants compete for light when nutrients are abundant. The results are that few high-yield species thrive, thereby causing a reduction in biodiversity. The eventual decomposition of these high-yielding species consumes the oxygen necessary for other aquatic life.

After chromic acid rinsing technology attained a near-mature status, many professional articles dedicated to further improvements also mentioned chrome toxicity. This toxicity is related to the ability of $\mathrm{Cr}(\mathrm{VI})$ to cross cell walls through a pathway intended for sulphate anions [19]. Then, the reduction of $\mathrm{Cr}(\mathrm{VI})$ inside the cell will damage DNA. In fact, $\mathrm{Cr}$ (VI) was shown to have 100 times the toxicity of $\mathrm{Cr}$ (III) [20].

Nickel contained in conversion coatings solutions was also shown to have toxicity in both wastewater treatment plants and humans. For example, during wastewater treatment, it is important to consider both aerobic and anaerobic biological processes. However, anaerobic treatment contains a limited variety of life forms and suffers loss of function at low incoming nickel concentrations; aerobic wastewater treatment are not as affected by nickel [21]. In humans, nickel (II) disrupts protein responses and biochemical pathways, both of which can be toxic [22].

\section{The Evolution of Conversion Coatings}

Table 1 lists three informative review articles [12,23,24] on conversion coatings, covering approximately a 50-year period. Although they, in general, cover common areas such as bath chemistry, patents, characterization and operational parameters, each also has useful contributions to the growing body of knowledge of these coatings technologies. Each review maintains a consistent approach that includes technology assessments of advances and the state-of-the-art in their respective eras. From the perspective of literary analysis, each review provided a foreshadowing of the next generation of conversion coatings, along with summaries of contemporaneous progress.

Table 1. Summary of contents within three prominent review papers on conversion coatings technologies.

\begin{tabular}{ccccc}
\hline Time & Author & Environmental & State of Art & Exceptional Topic \\
\hline 1980 & Bender et al. [23] & Minimal & Phosphate & Film Formation \\
2005 & Narayanan [24] & Recovery & Tri-cationic & Film Analysis \\
2018 & Milosev and Frankel [12] & Replace & $\mathrm{ZrO}_{2}$ & Adhesion-Delamination \\
\hline
\end{tabular}




\subsection{Conversion Coating [23]—Bender et al. (approx. 1970-1980)}

When Bender et al. of General Motors published this review, about 70 years of conversion coating developments had already transpired. In a remarkably succinct statement, they summarized auto body zinc phosphate baths of the period as containing four basic constituents:

- Water;

- Phosphoric Acid;

- A mixture of salts of zinc phosphate;

- Oxidizers.

Additional ingredients within the solutions were also used to improve coating speed and crystallinity, and to reduce sludge.

During the conversion coating process, any surface-borne substance on the automobile structure with the capacity to interfere with the intended chemical reactions most likely would become an unwelcome contaminant that required removal before processing. Alkaline cleaning was typical; it was the first metal cleaning process for automotive bodies. An analysis of incoming cold-rolled steel and the effects of angstrom-level organic carbon contamination were examined, and then correlated to annealing gas used during the cold-rolling process. Patents and relevant research on cleaning methods were also presented that focused on solvent and aqueous solutions, along with methods of measuring cleanliness.

Although bath formulations of the period were relatively similar, ample developments were occurring in a continuous discovery of improvements in both process and coating performance. The advances described included at least 18 oxidizers and 48 crystallinity modifiers, plus over 30 patents and research references that captured the most recent developments. Experimental results also showed the coating weight as a function of bath parameters such as concentrations, temperatures, steel sources and solution compositions.

Post-conversion coat-drying methods of the period depended on the next coating and typically accommodated a solvent-based or an aqueous-based electrodeposition layer. Solvent-based coatings saw little advantage from oven drying and merely required a surface free of standing water. On the other hand, drying at around $150{ }^{\circ} \mathrm{C}$ was optimum for primers formulated from waterborne paints.

The review also discussed the electrodeposition of resins that were applied to automotive bodies; this process had its start in the 1960s, although it is to be noted that observations of electrophoresis actually began in the early 1800s. In fact, a patent for electrodeposition on automobile parts was awarded in 1963, and the electrodeposition of automotive bodies began in around 1964 in Japan [25].

This review article closed with descriptions of future trends and advancements such as low-temperature baths, which played a major role in energy and cost reduction, anti-pollution phosphate coatings and non-destructive testing. As it turns out, the review was quite accurate in predicting relevant topics needing additional research and the rising importance of accounting for pollution.

In summary, the key points of the review were; an analysis of the phosphate baths and subsequent coatings, the interaction between conversion coating and electrodeposition, and body surface conditions.

\subsection{Conversion Coatings [24]—Narayanan (approx. 1980-2005)}

This review, published in 2005, opened with discussions of topics of the time, including low-temperature baths, low zinc concentration makeups, tricationic phosphating formulations, and an assessment of alternatives to hexavalent chrome treatment. Although it was not an automotive centric review, the body of material presented was very pertinent for understanding the evolution of pretreating automotive bodies.

In Section 3.3.2, Narayanan describes a process of forcibly spraying ions onto the surface. This is a "mechanical acceleration" of the coating process. A spray transports ions to the metal surface 
more rapidly than diffusion alone. A patent by Murakami et al. describes a "spray-dip" process, and it was particularly relevant to automotive bodies [26]. As the name suggests, it combines a spray process that quickly transports ions to readily accessible surfaces by means of mostly momentum and a dip processes that transports ions to complex hidden surfaces by means of mostly diffusion. Also relevant to automotive bodies was work by Losch et al. on measuring phosphate coating porosity by electrochemical means [27]. The uncoated surface area in the pores acts as an adhesion interface for ED (electrodeposition) and as a measure of coating coverage. ED is the layer between the conversion coating and the first paint layer, or primer.

Two important advancements of zinc phosphate baths were, first, calcium-modified baths and, second, $\mathrm{Ni}$ and $\mathrm{Mn}$ modified baths that were also known as tri-cationic baths. Calcium was found to reduce the crystalline grain size from $25 \mu \mathrm{m}$ to around $4 \mu \mathrm{m}$ and, thereby, became associated with improved corrosion resistance. Work by Bhar et al. on the effects of calcium ions in zinc phosphate baths included SEM observations of grain size reduction [28]. They go on to say other ions such as calcium, barium, nickel, fluoride, etc. achieve the preferred coating morphology ("compactness, grain size, grain distribution), however, most of that work was mentioned in patents rather than the body of literature. On salt their spray tests, scholzite $\left(\mathrm{CaZn}_{2}\left(\mathrm{PO}_{4}\right)_{2} \cdot \mathrm{H}_{2} \mathrm{O}\right) /$ hopeite performed better than phosphophyllite/hopite.

The presence of $\mathrm{Ni}$ and $\mathrm{Mg}$ ions caused the modification of hopeite precipitates into a form that had similar thermal and corrosion resistance to phosphophyllite; also, importantly, this modified coating formed on Zn-coated steel. Phosphophyllite is more chemically stable than hopeite. Furthermore, coating properties were improvable by manipulating the ratio of phosphophyllite to total composition [29], as defined below.

$$
\begin{gathered}
{[\mathrm{P}] /([\mathrm{P}]+[\mathrm{H}])} \\
{[\mathrm{P}]=\text { amount of phosphophyllite }} \\
{[\mathrm{H}]=\text { amount of hopeite }} \\
2 \mathrm{H}_{2} \mathrm{O}+2 \mathrm{e}^{-} \rightarrow \mathrm{H}_{2}+2 \mathrm{OH}^{-}
\end{gathered}
$$

During cathodic electrodeposition (ED), water is reduced (Equation 13) at the cathode.

The presence of hydroxyl ions in solution causes relatively fast dissolution [24] of the less robust hopeite phase in the conversion coating layer. Hence, to prevent the excess corrosion of the protective coating layer, a layer richer in the more robust phosphophyllite phase seemed to be an obvious requirement. However, since pre-coated body panels would have a Zn surface, no iron was available from which to form a robust precipitate. There was a need for simultaneously obtaining robust corrosion protection, an ability to withstand the high $\mathrm{pH}$ environment of $\mathrm{ED}$, and a coating on a zinc surface.

An automotive company patent (Alkaline resistant manganese-nickel-zinc phosphate conversion coatings and method of application) of the period states, with respect to a phosphate coatings consisting of these three divalent ions, "[such coatings] provide a base for paint adhesion and to inhibit the undercutting of paint in a corrosive environment". The patent continues with discussion specifically related to pretreatment of "zinc metal articles or substrates" [30].

The long-term embodiment of this technology was tricationic pretreatment containing $\mathrm{Ni}$ and $\mathrm{Mn}$ in conjunction with low $\mathrm{Zn}$ concentrations. For automotive bodies, tricationic baths were implemented for conversion coating compatibility with multi-body (galvanized and aluminum surfaces) fabrication and cathodic electrodeposition. The general formula is shown in Equation (14).

$$
\mathrm{Zn}_{3-x-z}\left(\mathrm{Ni}_{x} \mathrm{Mn}_{z}\right)\left(\mathrm{PO}_{4}\right)_{2} \cdot 4 \mathrm{H}_{2} \mathrm{O}
$$

Narayanan [24] discussed testing and measurements with analytic instrumentation to characterize conversion coatings and detect different phases more extensively than previous reviews. Examples of 
the analytic methods that could compare the tricationic phase to phosphophyllite are differential thermal analysis (DTA) and differential scanning calorimetry (DSC). Importantly, DTA showed a temperature difference of $50{ }^{\circ} \mathrm{C}$ between the endothermic peaks of hopeite (at $\sim 110{ }^{\circ} \mathrm{C}$ ) and phosphophyllite (at $\sim 160^{\circ} \mathrm{C}$ ). Hopeite which contained $1.8 \mathrm{wt} \% \mathrm{Ni}$ and $\mathrm{Mn}$ saw the endothermic peak increase to about $\sim 150{ }^{\circ} \mathrm{C}$. At $5.6 \mathrm{wt} \% \mathrm{Ni}$ and $\mathrm{Mg}$, the endothermic peaks matched that of phosphophyllite. The DSC results indicated that tri-cationic phosphate was preventing rehydration when compared to unmodified zinc phosphate.

This review included two sections on testing the quality of a coating. The first was on physical characteristics, the second on corrosion performance. The corrosion section included environmental stress tests and electrochemical testing. Electrochemical testing in addition to highlighting failure modes, also explains the underlying physics. Work by Zurilla and Hospadaruk [31] analyzed a connection between porosity of phosphate coatings, oxygen reduction current, and hours to failure in a salt spray. In a review by Leidheiser [32] on methods for predicting corrosion at the metal-organic interface, which is of critical interest in the case of automotive bodies, the work of Zurilla and Hospadaruk was summarized. Since the cathodic half of the redox equation occurring at a defect in the paint coating develops a high $\mathrm{pH}$, this lead the researchers to a polarization experiment measuring oxygen reduction current while in a similar high $\mathrm{pH}$ environment. Their results indicated lower activity (due to less porosity) at the defect site correlated with longer time to failure in a salt spray test.

As foreshadowed in articles published prior to this review, environmental concerns continued to grow. Discussions of solutions to the solid waste problem included patents on metal recovery and their secondary use in markets such as lubricants or concrete filler. The environmental concerns about phosphating's waste streams were approaching the point of disruption by an alternative technology.

Since Narayanan's review was so comprehensive, confining its key points to only automotive body applications is somewhat of an injustice. However, in summary, the explanation for the development of tricationic phosphating and its compatibility with electrodeposition and multi-body materials was an outstanding contribution that highlighted advancements in conversion coatings technology.

\subsection{Conversion Coatings [12]-Milosev and Frankel (approx. 2000-2018)}

This reveiw began with the benefits/effects of chromates, heavy metals and phosphates, and then progressed into a discussion of zirconium oxide (or titanium) conversion coatings. Their introduction captured many of the forces driving $\mathrm{Zr}$ oxide coating technologies as an alternative to phosphating. Their review was not automotive centric, however, again, it contained pertinent knowledge that is part of the thread of evolution in auto body pretreatment, Another important connection to automotive bodies was extensive description of experimental results on $\mathrm{Al}$ and its automotive relevant $5 \mathrm{xxx}$ and 6xxx alloys.

A solution with hexafluoro zirconium [33] (or titanic) acid-i.e., $\mathrm{H}_{2} \mathrm{ZrF}_{6}$-coupled with a surface redox reaction that increased local $\mathrm{pH}$ yielded a precipitate deposit of metal $\mathrm{Zr}$ or Ti) oxide. Although the reaction steps of metal oxide deposition are different from metal phosphate deposition, both are $\mathrm{pH}$-driven reactions [34].

Examples of the precipitation reactions are presented in Equations (15) and (16) in which a localized $\mathrm{pH}$ increase led to the cathodic reaction consuming localized $\mathrm{H}^{+}$.

$$
\begin{gathered}
\mathrm{ZrF}_{6}{ }^{2-}(\mathrm{aq})+4 \mathrm{OH}^{-} \rightarrow \mathrm{ZrO}_{2} \cdot 2 \mathrm{H}_{2} \mathrm{O}(\mathrm{s})+6 \mathrm{~F}^{-}(\mathrm{aq}) \\
\mathrm{Zr}_{4}{ }^{+}+3 \mathrm{H}_{2} \mathrm{O} \rightarrow \mathrm{ZrO}_{2} \cdot 2 \mathrm{H}_{2} \mathrm{O}(\mathrm{s})+4 \mathrm{H}^{+}
\end{gathered}
$$

As mentioned previously, one remarkable property of chromate treatment, but not unique to metal compounds [35,36], was the apparent effect of self-healing. In the intervening years from 1980 or so, significant advancements in alternative self-healing materials were introduced. Examples are the effects obtained from vanadium and cerium [37]. 
On auto bodies, zirconium coatings are thinner than phosphate coating by as much as three orders of magnitude. Mohammadzade and Ghanbari [38] researched the $\mathrm{ZrO}_{2}$ filming process and concluded that formation consisted of three distinct phases starting with precipitation, then growth, and finally, a self-limiting dynamic equilibrium due to decreased cathodic reaction. In such a final state, the rate of precipitation from solution is equal to the rate of coating dissolution as evidenced by changing surface topography [38], albeit without changes in $\mathrm{Zr}$ concentration in the solution. Thicker phosphate coatings "covered and filtered" body panel topography and tooling marks, however, thinner $\mathrm{ZrO}_{2}$ will "transmit" these usually undesirable features.

Prior to coating the body with phosphate, an aqueous immersion process "activates" the surface. Activation leaves behind nucleation sites for epitaxial phosphate crystal growth that occurs mostly parallel to the surface and reaches a limit by contact with growth from neighboring nucleation sites. For the case of a zirconium coating, Lunder et al. used EDS to determine that $\mathrm{ZrO}_{2}$ is an amorphous layer [39]. $\mathrm{ZrO}_{2}$ deposits on the surface without crystal growth. This eliminates the separate activation layer process and is an operational and capital cost reduction for automakers. Lunder et al. also [39] mentioned the need for agitating the solution in order to achieve more uniform coating. In automotive baths, the same principle applies, although on an industrial scale.

Although a separate activation process tank is not needed, a surface activation consisting of dissolution of oxide is intrinsic to the overall $\mathrm{ZrO}_{2}$ process [40].

Phosphate has a long history for use as paint adhesion and corrosion protection. $\mathrm{ZrO}_{2}$ must improve or maintain those characteristics in order to be a viable process. Research by Frankel and Khun concluded that indeed hexafluorozirconic acid surface treatment is an effective process to improve corrosion resistance and to slow organic coating delamination by the mechanism of cathodic delamination [41].

The review assessed the merits associated with delamination mechanisms and the coating's adhesion strength. Organic coatings, such as epoxy, polyester and polyurethane, protect against bulk electrolyte (e.g., road salt and water), however, they are water permeable and as a result, corrosion at the film/coating interface would ensue. Hence, two crucial failure modes were identified, including wet adhesion and cathodic delamination.

An example of wet adhesion testing was a 20-day soak in 3.5\% sodium chloride followed by an adhesion loss calculation, as shown in Equation (17).

$$
\text { Adhesion loss } \%=(1-(\text { recovery adhesion }) /(\text { dry adhesion })) \times 100 \%
$$

Physical damage of the coating stack allowed the anodic corrosion of the base metal, which provided electrons to be available at cathodic sites of the organic and conversion-coating interface where hydroxyl ions were also present because of oxygen reduction. An abundance of $\mathrm{OH}^{-}$at the interface led to weakening of adhesion through alkalization. This process is defined as cathodic delamination and is inversely related to a coating's surface roughness.

This review concluded with a summary of $\mathrm{Zr}$ and Ti conversion coatings that were found to have increased adhesion and reduced cathodic delamination compared to untreated surfaces. In closing, the review emphasized the importance of considering the entire coating stack as a system and a warning that an assessment of pretreatment alone was not a guarantee of overall system performance.

\subsection{Connecting The Nearly 50 Years of Progress in Conversion Coatings: Approximately 1970-2018}

The three reviews $[12,23,24]$, although separated by time, authorship and geography, have formed an enlightening narrative that reveals the interesting evolution of automotive body conversion coatings technologies.

From an environmental perspective, the long-term trend for metal phosphate has leaned towards its replacement by zirconium oxide; however, the operational cost differential is not compelling enough to drive an immediate replacement of the legacy automotive phosphate processes. As it turns out, 
a significant environmental impact that drives the changeover to $\mathrm{ZrO}_{2}$ comes not only from the pretreatment process but also from lightweighting in the body design process. State-of-the-art designs have pushed new materials into the manufacture of automotive bodies that, in turn, have driven accommodations by new pretreatment technologies.

At the time of Bender's review [23], a developing technology applicable to car bodies was electrodeposition (ED). Early ED technology was anodic in nature; this meant negatively charged colloid material was attracted to the anode and underwent neutralization and coagulation in the acidic boundary at the positively charged (anode) body surface. As it turned out, this acidic boundary layer was equivalent to the inversion of the phosphating process [42]. Subsequently, ED migrated to a cathodic process where positively charged colloid material migrated to a negatively charged (cathode) car body. In this case, the boundary layer was alkaline due to the $\mathrm{OH}^{-}$generated by electrochemical decomposition of water at the cathode; advantages of cathodic electrodeposition precluded both metal dissolution and electrochemical oxidation of resin at the body panel surface.

Narayanan's review [24], as a follow-up to Bender's review, included an extensive analysis of the tri-cationic phase and explained why it had robustness similar to phosphophyllite. The final section of this review indicated that phosphate waste streams were becoming a topic of research and patent activity. However, the focus was on the recovery of waste rather than replacement of the entire process.

A trend seen in the Milosev and Frankel review [12] was also occurring in the automobile industry as it accommodated multi-body metals. The two earlier reviews mentioned $\mathrm{Al}$ as a generic metal. In contrast, Milosev and Frankel covered $\mathrm{Al}$ in an important two-fold sense. First, $\mathrm{Al}$ received coverage as a separate and distinct metal; second, specific $\mathrm{Al}$ alloys were discussed. As it turns out the $5 \mathrm{xxx}$ and 6xxx alloys have found use in vehicles and are also so-called "military grades". Moreover, research on $\mathrm{Mg}$ coatings was included. While all three reviews mentioned the toxicity of hexavalent chrome, the discussion in the Milosev and Frankel's assessed chromium's effectiveness, but not its application.

All three reviews had a system engineering approach in considering the base metal all-the-way through the organic coating, or paint: i.e., all the layers shown in Figure 1, as a system. Although evaluating the conversion coating as an individual step has value, the ultimate determination of performance actually depended on the entire stack of layers. Each review offered a unique perspective and important knowledge. For example, the Bender review of 1980 [23] discussed erosion of the conversion coating due to ED and included a measure of this erosion in a plot of pore density-vs.-ED time. Narayanan [24] covered topics such as rehydration stresses that reduce paint to phosphate adhesion. In Milosev and Frankel [12], an extensive section on delamination mechanisms was included. They concluded their review by expressing the necessity of evaluating the full stack of coatings rather than only the component layers.

\section{Magnesium}

Since Mg coatings have been discussed [12], the question has arisen: What are the barriers for further utilization of this lightweight structural metal in automobile bodies? An answer was recently formulated [43]: it turns out that the costs of the primary metal in combination with its deployment with cost-effective anticorrosion technologies are currently prohibitive. In addition to these costs, a potential exists for unwanted or unplanned price fluctuations as a consequence of the current relatively small scale of magnesium availability; large increases in Mg costs may occur with its widespread use in automobiles.

Magnesium also has process compatibility issues with legacy pretreatment lines [44]. First, Mg requires acid versus alkaline cleaning and, second, it contaminates zinc phosphates baths [44]. Another important process that still requires substantial research is the formability of $\mathrm{Mg}$ wrought alloys. A statement about its status, but not its catch-up time, is that " $\mathrm{Mg}$ corrosion understanding is 20 years behind $\mathrm{Al}$ and 40 years behind that of steel" [44]. Overall, $\mathrm{Mg}$ requires further research for understanding its viability in harsh environments; nevertheless, it is already used in automobiles 
in the form of die-castings in areas safer from corrosion attack such as in engine compartments and interiors.

\section{Tri-Cationic Phosphate Pretreatment Process}

Figure 6 illustrates a state-of-the-art tri-cationic phosphate pretreatment process. According to the timeline in Figure 2, this technology went into practice around 1985. Since it is mature, with well-known corrosion field performance, phosphate coatings are widely used.

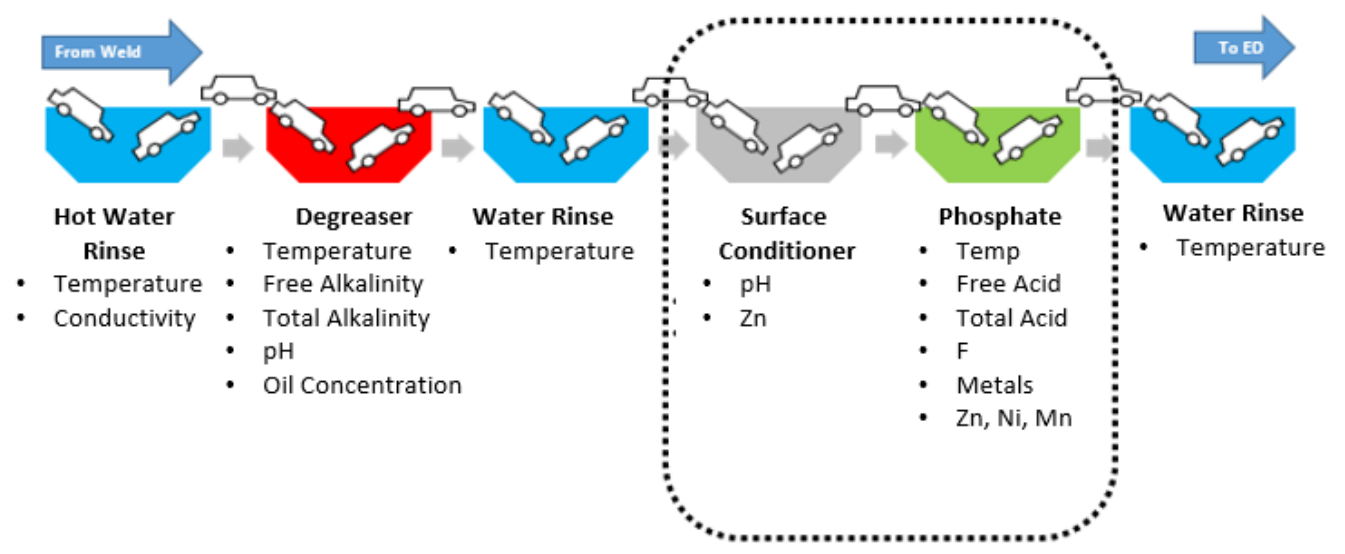

Figure 6. Tricationic zinc phosphate conversion coating line.

\section{Zirconium Oxide Pretreatment Process}

Figure 7 illustrates two possible configurations of $\mathrm{ZrO}_{2}$ pretreatment technology. The upper part of the figure-labelled as the brown field-represents the conversion of an existing phosphate line. The lower part of figure-labelled as the green field—represents a new technology installation.

The conversion of an existing phosphate line to a $\mathrm{ZrO}_{2}$ pretreatment line has a significant transitional cost associated with the deep cleaning of the $\mathrm{PO}_{4}$ stage. However, $\mathrm{ZrO}_{2}$ operates at temperature ranges already used by automobile manufacturers.

New $\mathrm{ZrO}_{2}$ pretreatment installations would have lower startup costs than new tri-cationic phosphate installations. The reasons for this reduced cost include the following: first, the treatment tank can be smaller; second, no need exists for a surface activation tank; and third, $\mathrm{ZrO}_{2}$ pretreatment requires less filtration requirements, leading to both lower startup and operational costs.

On the other hand, $\mathrm{Zr}$ oxide layers are much thinner $\left(\sim 50-500 \times 10^{-9} \mathrm{~m}\right)$ and, therefore, have fewer masking properties than a typical, thicker zinc phosphate layer $\left(20 \times 10^{-6} \mathrm{~m}\right)$. A thicker $\mathrm{PO}_{4}$ layer acts as a filter that smooths a wider range of underlying body metal topography.

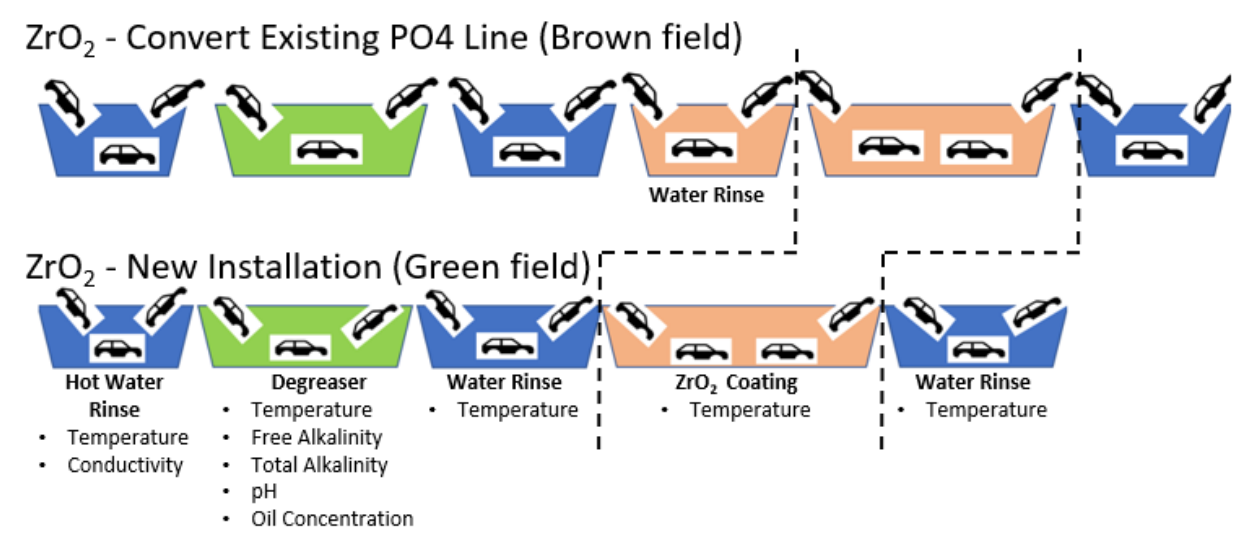

Figure 7. Zirconium conversion coating processes. 


\section{Conclusions}

Currently, tri-cationic phosphate pretreatment processes continue to be widely used for automotive bodies. This continued use is firstly a result of the technology being a well-accepted, mature technology with known corrosion and field performance. Secondly, US automotive manufacturers have an exemption that enables the disposal of sludge without classifying it as a hazardous waste. However, this exemption in environmental rules is not universal since sludge disposal costs are subject to regional regulations. Thirdly, a reasonable percentage of $\mathrm{Al}$ body parts are tolerable within an automobile. On the other hand, eventual "cradle-to-grave" lifecycle responsibilities, especially for sludge waste, will increase the associated costs of phosphate over the long term. Although chromate rinsing had a history as a follow-on to body phosphating, it was fortunately discontinued in the 1990s, thereby eliminating a rather dangerous waste stream.

Zirconium oxide conversion coatings offer several advantages over tri-cationic phosphating. Sludge reduction is as high as $95 \%$; processing at ambient temperature is possible, thereby reducing energy consumption; and $\mathrm{Zr}$ has a significant environmental characteristic because of its low toxicity [45]. However, one of the most significant industrial advantages of $\mathrm{ZrO}_{2}$ is enabling a higher $\mathrm{Al}$ surface area in automotive bodies without detrimental effects.

Lightweighting combined with commensurate powertrain resizing improves fuel economy by $7 \%$ for each $10 \%$ of weight reduction [46]. An emphasis on lightweight materials, however, places new demands on surface pretreatment coatings for corrosion protection and paint adhesion. High-strength steels and aluminum alloys contribute to weight reduction and are compatible with legacy body manufacturing processes. Operationally, as the $\mathrm{Al}$ content exceeds approximately $30 \%$ of the total body panel, $\mathrm{Zr}$ oxide pretreatment becomes a preferred process because, at these $\mathrm{Al}$ levels, zinc phosphate baths become difficult to control and generate high amounts of sludge [47]. In fact, Zr oxide pretreatment enables car bodies with aluminum content up to $85 \%$. In summary, Al content is a key factor in pretreatment decisions and is driven by so-called greener manufacturing and design processes.

In addition to the vehicular benefits of lightweighting and $\mathrm{ZrO}_{2}$, environmental benefits are present in the upstream supply chain of Al. Some producers of Al metal have significantly reduced their emissions, decreased their water consumption by $50 \%$, and diminished their energy consumption by $30 \%$ [47].

Looking at the overall evolution of automobile body pretreatments, it is clear that the quality and reliability of the total coating system, from activation-through-clear coat, were key drivers of advancements. However, environmental impact considerations have not only played a direct role in terms of investment and operational decisions of both chemical suppliers and the body coating process, but also in the body design process. The DfE approach (design for environment) is driving advancements in lightweighting with new materials, which in turn drives further pretreatment development needs.

In closing, the article has chronologically connected primary sources through a concerted effort to assess many years of publications, and to describe the evolution of conversion coatings along the timeline presented in Figure 2. It should answer the following question: where did it start, and how did this technology evolve to current operating configurations? Overall, the intended audience ranges from those with no experience to a professional with more long-term experience.

Author Contributions: Conceptualization N.K.A; Writing-Original Draft Preparation, G.P, L.H., and M.D; Writing-Review \& Editing N.K.A, G.P, L.H., and M.D.

Funding: This research received no external funding.

Acknowledgments: This work was partially supported by development funds of the Institute of Research for Technology Development (IR4TD) College of Engineering, University of Kentucky.

Conflicts of Interest: The authors declare no conflict of interest. 


\section{References}

1. Coslett, T.W. Treatment of Iron or Steel to Prevent the Oxidation or Rusting Thereof. U.S. Patent 1,007,069, 31 October 1911.

2. Mills, P. What's cooking in chemical pretreatment? Available online: http://www.powdercoatedtough.com/ News/ID/572/Whats-Cooking-In-Chemical-Pretreatment (accessed on 7 September 2018).

3. Akafuah, N.; Poozesh, S.; Salaimeh, A.; Patrick, G.; Lawler, K.; Saito, K. Evolution of the automotive body coating process-A review. Coatings 2016, 6, 24. [CrossRef]

4. Giles, T.R.; Goodreau, B.H.; Fristad, W.E. An update of new conversion coating for the automotive industry. SAE Int. J. Mater. Manuf. 2008, 1, 575-581. [CrossRef]

5. Rausch, D.W. The Phosphating of Metals; ASM International: Metals Park, OH, USA, 1990.

6. Giles, T. Pretreatment for Painting. Available online: https://www.pfonline.com/articles/pretreatment-forpainting (accessed on 7 September 2018).

7. Streitberger, H.-J.; Dossel, K.-F. Automotive Paints and Coatings, 2nd ed.; Wiley-VCH: Weinheim, Germany, 2008.

8. Wolpers, M.; Angeli, J. Activation of galvanized steel surfaces before zinc phosphating-XPS and GDOES investigations. Appl. Surf. Sci. 2001, 179, 281-291. [CrossRef]

9. Jernstedt, G. Corrosion Resistant Coating for Metal Surfaces. U.S. Patent 2,310,239, 9 February 1943.

10. Tegehall, P.-E. The mechanism of chemical activation with titanium phosphate colloids in the formation of zinc phosphate conversion coatings. Colloids Surf. 1990, 49, 373-383. [CrossRef]

11. Klusmann, E.; Schultze, J.W. pH-microscopy: Technical application in phosphating solutions. Electrochimica Acta 2003, 48, 3325-3332. [CrossRef]

12. Milošev, I.; Frankel, G.S. Review—conversion coatings based on zirconium and/or titanium. J. Electrochem. Soc. 2018, 165, 127-144. [CrossRef]

13. Hagans, P.; Haas, C. ASM Handbook Volume 5: Surface Engineering; ASM International: Metals Park, $\mathrm{OH}$, USA, 1994.

14. Zhang, X.; Sloof, W.; Hovestad, A.; Westing, E.V.; Terryn, H.; Wit, J.D. Characterization of chromate conversion coatings on zinc using XPS and SKPFM. Surf. Coat. Technol. 2005, 192, 168-176. [CrossRef]

15. Flora, S.D.; Camoirano, A.; Bagnasco, M.; Bennicelli, C.; Corbett, G.; Kerger, B. Estimates of the chromium(VI) reducing capacity in human body compartments as a mechanism for attenuating its potential toxicity and carcinogenicity. Carcinogenesis 1997, 18, 531-537. [CrossRef] [PubMed]

16. Puomi, P.; Fagerholm, H.; Sopanen, A. Parameters affecting long-term performance of painted galvanised steels. Anti-Corros. Methods Mater. 2001, 48, 160-171. [CrossRef]

17. Smolders, A.J.; Lucassen, E.C.; Bobbink, R.; Roelofs, J.G.; Lamers, L.P. How nitrate leaching from agricultural lands provokes phosphate eutrophication in groundwater fed wetlands: The sulphur bridge. Biogeochemistry 2010, 98, 1-7. [CrossRef]

18. Lamers, L.P.M.; Falla, S.-J.; Samborska, E.M.; van Dulken, I.A.; Hengstum, G.V.; Roelofs, J.G. Factors controlling the extent of eutrophication and toxicity in sulfate-polluted freshwater wetlands. Limnol. Oceanogr. 2002, 47, 585-593. [CrossRef]

19. Salden, M.P. Chromium: Environmental, Medical and Materials Studies (Chemical Engineering Methods and Technology); Nova Science Pub Inc.: Hauppauge, NY, USA, 2011.

20. Saha, R.; Nandi, R.; Saha, B. Review sources and toxicity of hexavalent chromium. J. Coord. Chem. 2011, 64, 1782-1806. [CrossRef]

21. Sujarittanonta, S.; Sherrard, J.H. Activated sludge nickel toxicity studies. J. Water Pollut. Control. Fed. 1981, 53, 1314-1322.

22. Ge, Y.; Bruno, M.; Haykal-Coates, N.; Wallace, K.; Andrews, D.; Swank, A.; Winnik, W.; Ross, J.A. Proteomic assessment of biochemical pathways that are critical to nickel-induced toxicity responses in human epithelial cells. PLoS ONE 2016, 11, e0162522. [CrossRef] [PubMed]

23. Bender, H.S.; Cheever, G.D.; Wojtkowiak, J.J. Zinc phosphate treatment of metals. Prog. Org. Coat. 1980, 8, 241-274. [CrossRef]

24. Sankara Narayanan, T.S.N. Surface pretreatment by phosphate conversion coatings-A review. Rev. Adv. Mater. Sci. 2005, 9, 130-177. 
25. Oyabu, Y.; Furuno, N.; Hirasawa, Y.; Omori, H. Electrodeposition coating process for automobile bodies. Trans. Iron Steel Inst. Jpn. 1983, 23, 994-1008. [CrossRef]

26. Murakami, R.; Shimizu, H.; Yoshi, T.; Ishida, M.; Yonekura, H. Phosphating Process of Metal Surface. U.S. Patent 4,419,147, 6 December 1983.

27. Losch, A.; Schultze, J.W.; Speckmann, H.-D. A new electrochemical method for the determination of the free surface of phosphate layers. Appl. Surf. Sci. 1991, 52, 29-38. [CrossRef]

28. Bhar, G.N.; Debnath, N.C.; Roy, S. Effects of calcium ions on the morphology and corrosion resistance of zinc-phosphated steel. Surf. Coat. Technol. 1988, 35, 171-179. [CrossRef]

29. Satoh, N. Effects of heavy metal additions and crystal modification on the zinc phosphating of electrogalvanized steel sheet. Surf. Coat. Technol. 1987, 30, 171-181. [CrossRef]

30. Huff, J.; Zurilla, R. Alkaline Resistant Manganese-Nickel-Zinc Phosphate Conversion Coatings and Method of Application. U.S. Patent 4,596,607, 24 June 1986.

31. Zurilla, R.; Hospadaruk, V. Quantitative Test for Zinc Phosphate Coating Quality, SAE Technical Paper Series No. 780187, 762-767.

32. Leidheiser, H., Jr. Electrical and electrochemical measurements as predictors of corrosion at the metal-organic coating interface. Prog. Org. Coat. 1979, 7, 79-104. [CrossRef]

33. Karmaschek, U.; Roland, A.; Vennschott, H.; Wennemann, H. Chromium-Free Conversion Coating Treatment of Aluminum. U.S. Patent 5,584,946, 17 December 1996.

34. Li, L.; Desouzac, A.L.; Swain, G.M. In situ pH measurement during the formation of conversion coatings on an aluminum alloy (AA2024). Analyst 2013, 138, 4398-4402. [CrossRef] [PubMed]

35. Hass, D. Self-Healing Environmental Barrier Coating. U.S. Patent 9,951,630, 24 April 2018.

36. Braun, P.V.; Choo, S.H.; White, S.R. Self-healing Coating System. U.S. Patent 7,723,405, 25 May 2010.

37. Zhong, X.; Wu, X.; Jia, Y.; Liu, Y. Self-repairing vanadium-zirconium composite conversion coating for aluminum alloys. Appl. Surf. Sci. 2013, 280, 489-493. [CrossRef]

38. Ghanbari, A.; Attar, M.M. Self-limiting film formation mechanism of zirconium based conversion coating on mild steel. Anti-Corros. Methods Mater. 2016, 63, 137-144.

39. Lunder, O.; Simensena, C.; Yub, Y.; Nisancioglub, K. Formation and characterization of Ti-Zr based conversion layers on AA6060 aluminium. Surf. Coat. Technol. 2004, 84, 278-290. [CrossRef]

40. Li, L.; Whitman, B.W.; Swaina, G.M. Characterization and performance of a Zr/Ti pretreatment conversion coating on AA2024-T3. J. Electrochem. Soc. 2015, 162, C279-C284. [CrossRef]

41. Khun, N.W.; Frankel, G.S. Effect of hexafluorozirconic acid pretreatment on cathodic delamination of epoxy coatings from steel substrates. Corrosion 2015, 71, 277-284. [CrossRef]

42. Beck, F. Fundamental aspects of electrodeposition of paint. Prog. Org. Coat. 1976, 4, 1-60. [CrossRef]

43. Joost, W.J.; Krajewski, P.E. Towards magnesium alloys for high-volume automotive applications. Scr. Mater. 2017, 128, 107-112. [CrossRef]

44. Brady, M.; Joost, W.J.; Warren, C.D. Insights from a recent meeting: Current status and future directions in magnesium corrosion research. Corrosion 2017, 73, 452-462. [CrossRef]

45. Couture, P.; Blaise, C.; Cluis, D.; Bastien, C. Zirconium toxicity assessment using bacteria, algae, fish assays. Water Air Soil Pollut. 1989, 47, 87-100. [CrossRef]

46. Joost, W. Reducing vehicle weight and improving U.S. Energy efficiency using integrated computational materials engineering. JOM 2012, 64, 1032-1038. [CrossRef]

47. Karpel, S. Advancing on All Fronts; Metal Bulletin: London, UK, 2013; pp. 37-40.

(C) 2018 by the authors. Licensee MDPI, Basel, Switzerland. This article is an open access article distributed under the terms and conditions of the Creative Commons Attribution (CC BY) license (http://creativecommons.org/licenses/by/4.0/). 